\title{
QUEEN'S
UNIVERSITY
BELFAST
}

\section{Thermal properties and eutectic behaviour of dapivirine in combination with steroid hormones and other antiretrovirals}

Malcolm, K., McCoy, C., Murphy, D., Boyd, P., Kumar, S., Fetherston, S., Brimer, A., Holt, J., Devlin, B., Blanda, W., Nuttall, J., \& Gilmour, C. (2014). Thermal properties and eutectic behaviour of dapivirine in combination with steroid hormones and other antiretrovirals. Poster session presented at HIV R4P - HIV Research for Prevention, Cape Town, South Africa. http://hivr4p.org/program/posters/posters-theme

Queen's University Belfast - Research Portal:

Link to publication record in Queen's University Belfast Research Portal

Publisher rights

Copyright 2014 The Authors

\section{General rights}

Copyright for the publications made accessible via the Queen's University Belfast Research Portal is retained by the author(s) and / or other copyright owners and it is a condition of accessing these publications that users recognise and abide by the legal requirements associated with these rights.

Take down policy

The Research Portal is Queen's institutional repository that provides access to Queen's research output. Every effort has been made to ensure that content in the Research Portal does not infringe any person's rights, or applicable UK laws. If you discover content in the Research Portal that you believe breaches copyright or violates any law, please contact openaccess@qub.ac.uk. 


\section{THERMAL PROPERTIES AND EUTECTIC BEHAVIOUR OF DAPIVIRINE IN COMBINATION WITH STEROID HORMONES AND OTHER ANTIRETROVIRALS}

Karl Malcolm', Clare McCoy ${ }^{1}$, Diarmaid Murphy ${ }^{1}$, Peter Boyd ', Sandeep Kumar ${ }^{1}$, Susan Fetherston ${ }^{1}$, Andrew Brimer ${ }^{2}$, Jonathon Holt ${ }^{2}$, Brid Devlin ${ }^{2}$, Wendy Blanda ${ }^{2}$, Jeremy Nuttall ${ }^{2}$, Chris Gilmour ${ }^{2}$

'Queen's University Belfast, UK, ${ }^{2}$ International Partnership for Microbicides (IPM), USA.

It is well established that the melting point of a drug is inversely proportional to its lipophilicity [e.g. Calpena et al., J Pharm Sci, 83 (1994) 29-33] which, in turn, correlates with its ability to be absorbed in vivo. Therefore, if the melting point of a drug can be reduced without affecting other physicochemical parameters then drug release and/or absorption may be enhanced. This oeneral principle has been exploited in a number of marketed pharmaceutical products, including the topical anaesthetic cream EMLA'm and the contraceptive vaginal ring Nuvaring ${ }^{\circledast}$. Both products contain two active pharmaceutical ingredients - EMLA ${ }^{\text {mic }}$ contains a mixture of prilocaine and lidocaine, while Nuvaring ${ }^{\oplus}$ contains etonogestrel and ethinyl estradiol (Fig. 1). Each drug in these combinations serves to reduce the melting point of the other drug, much in the same way that salt reduces the melting point of water (explaining use on icy roads). For example, the phase diagram for etonogestrel and ethinyl estradiol shows that the maximum reduction in drug melting point occurs for a 1:1 mixture (Fig. 2).
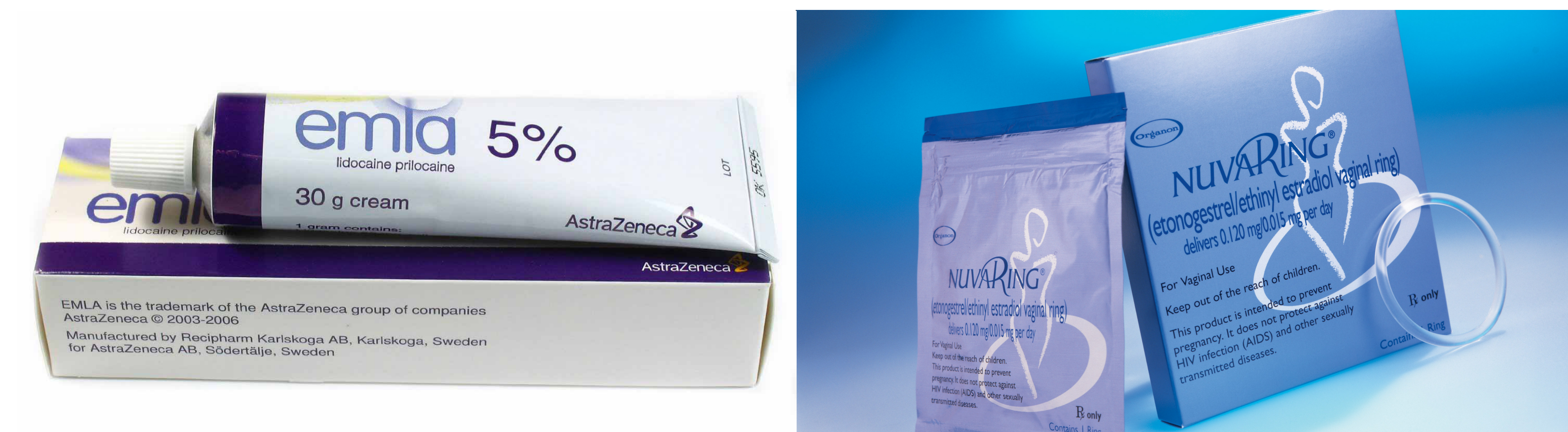

Figure 1. Examples of combination drug products formulated as eutectic mixtures.

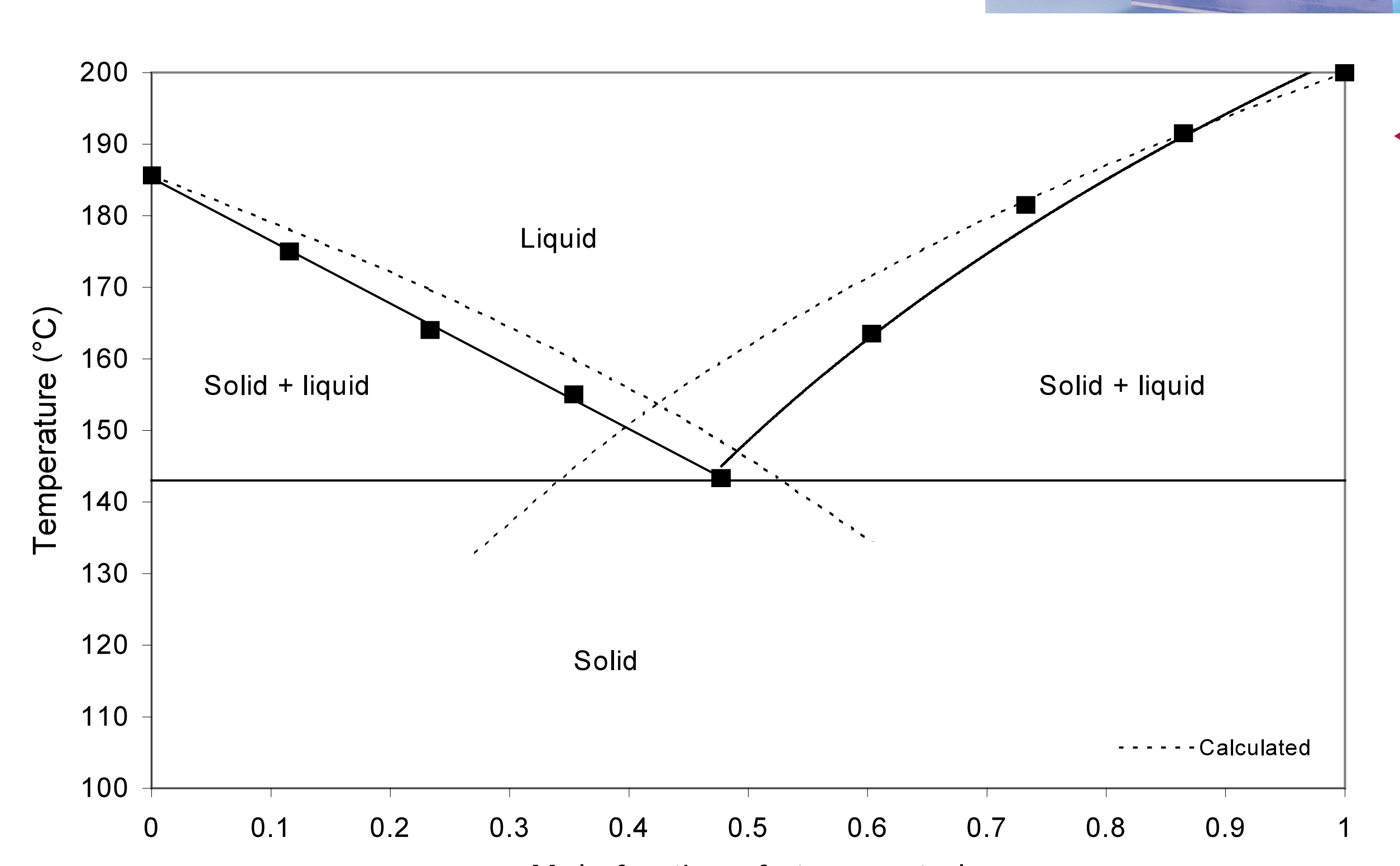

Figure 2. Phase diagram for etonogestrel and ethinyl estradio the drug components of Nuvaring [Van Laarhoven et al., Int J Pharm, 232 (2002) 163-173]

Combination microbicide and multipurpose prevention technology (MPT) products in which the active pharmaceutical ingredients are intimately associated may also offer increased drug release/ absorption on account of reduced melting behaviour. Here, we report that the lead antiretroviral microbicide candidate dapivirine (DPV) consistently forms eutectic or reduced melting temperature compositions with various antiretrovirals and steroid hormones that might be included as part of a MPT product.
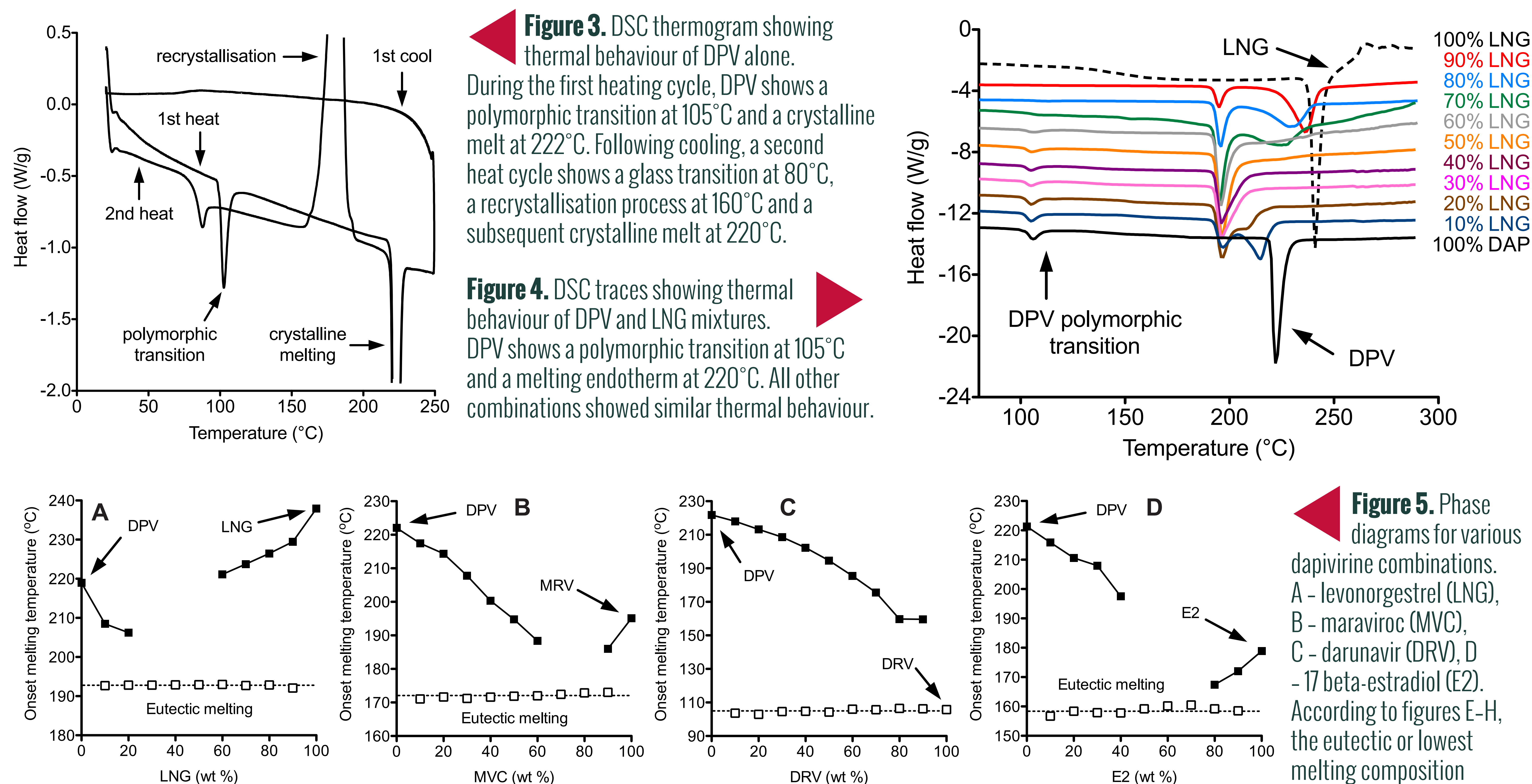

Figure 5. Phase diagrams for various dapivirine combinations. A - levonorgestrel (LNG), A - maraviroc (MVC)

- darunavir(DRV

- 17 beta-estradiol (E2) Accordino to fioures E-H, According to figures E-H
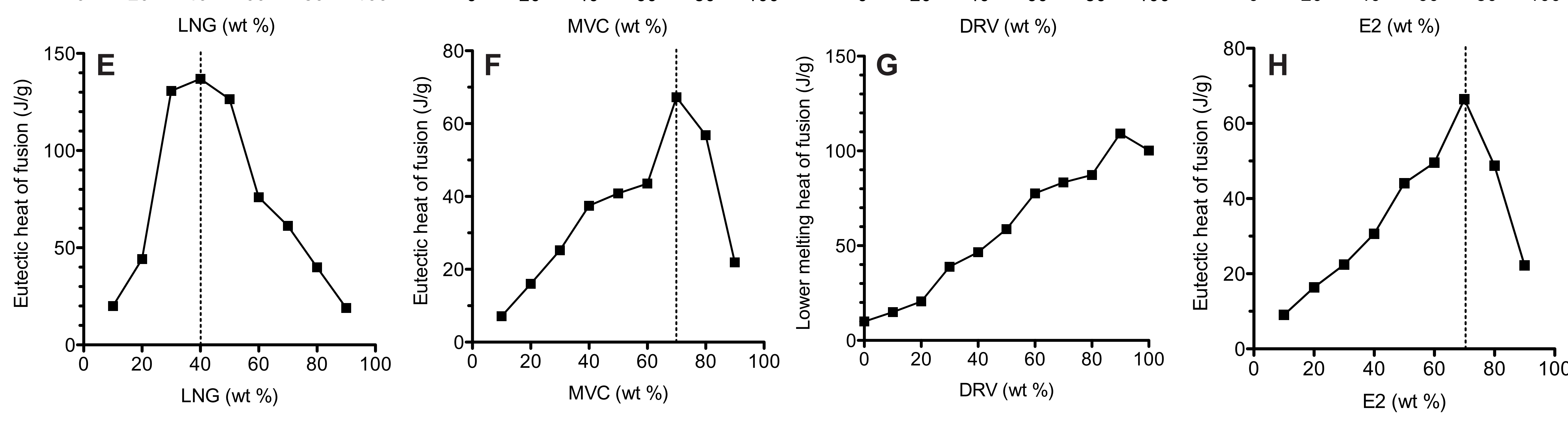
elting composition is determined as the cosstion having the grest heat of fusion value or the eutectic melting ransition. These eutectic compositions are indicated by a dashed line. 